\title{
8
}
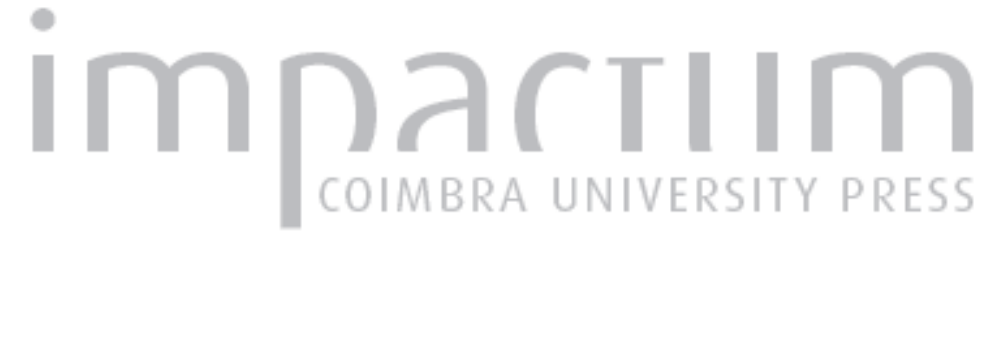

\section{[Recensão a] Rosalie Helena de Souza Pereira, Averróis, A arte de governar. Uma leitura aristotelizante da 'República'}

Autor(es): $\quad$ Carvalho, Mário Santiago de Publicado por: Faculdade de Letras da Universidade de Coimbra, Instituto de Estudos

URL

persistente:

DOI: $\quad$ DOI:http://dx.doi.org/10.14195/0872-0851_43_9

Accessed : $\quad$ 26-Apr-2023 12:10:34

A navegação consulta e descarregamento dos títulos inseridos nas Bibliotecas Digitais UC Digitalis, UC Pombalina e UC Impactum, pressupõem a aceitação plena e sem reservas dos Termos e Condições de Uso destas Bibliotecas Digitais, disponíveis em https://digitalis.uc.pt/pt-pt/termos.

Conforme exposto nos referidos Termos e Condições de Uso, o descarregamento de títulos de acesso restrito requer uma licença válida de autorização devendo o utilizador aceder ao(s) documento(s) a partir de um endereço de IP da instituição detentora da supramencionada licença.

Ao utilizador é apenas permitido o descarregamento para uso pessoal, pelo que o emprego do(s) título(s) descarregado(s) para outro fim, designadamente comercial, carece de autorização do respetivo autor ou editor da obra.

Na medida em que todas as obras da UC Digitalis se encontram protegidas pelo Código do Direito de Autor e Direitos Conexos e demais legislação aplicável, toda a cópia, parcial ou total, deste documento, nos casos em que é legalmente admitida, deverá conter ou fazer-se acompanhar por este aviso. 


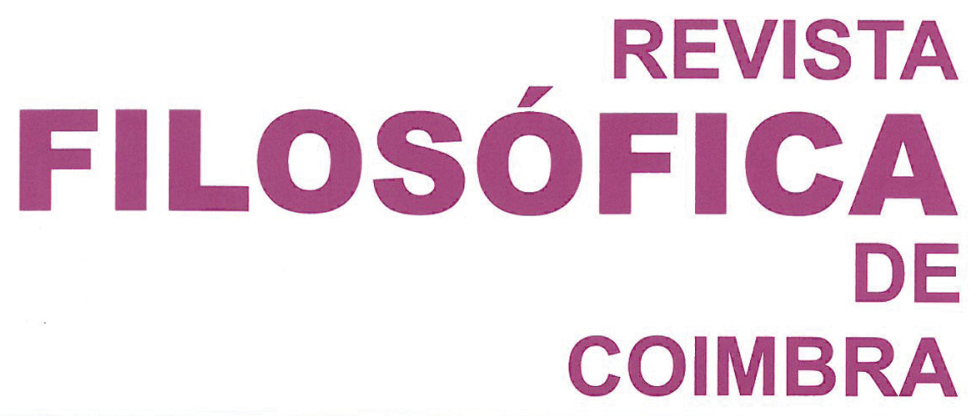

vol. 22 - número 43 - março 2013

vol. 22 - número 43 - março 2013

Fundação Eng. António de Almeida

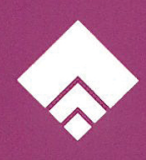




\section{RECENSÕES}

Rosalie Helena de Souza Pereira, Averróis, A arte de governar. Uma leitura aristotelizante da 'República'. Editora Perspectiva, São Paulo, 2012, 335pp.

É com um franco acolhimento que referimos nas páginas da nossa Revista a tese de doutoramento da A. defendida no IFCH-Unicamp (Brasil). Ela não só cumpre todos os requisitos de nível europeu para uma dissertação, como se apresenta, na nossa língua, como a melhor realização até hoje apresentada sobre o muçulmano hispânico Averróis (1126-1198), e designadamente sobre a sua filosofia política. Tratava-se, vale a pena sublinhá-lo, do capítulo menos estudado do contributo do pensador muçulmano. Um tal fito é alcançado, como não podia deixar de ser, mediante um estudo aturado, informado e sério do comentário que Averróis dedicou à República de Platão, haja em vista o facto de o Comentador de Aristóteles por antonomásia não ter tido acesso à Política do Estagirita. Estranha vicissitude da história literária a que Averróis foi sujeito e procurou deslindar da melhor forma possível. Na verdade, do seu trabalho chegou até nós uma tradução hebraica direta do árabe e duas traduções latinas derivadas daquela; ora, um mérito não menor da $\mathrm{A}$. passou por extrair uma consistente teoria política apoiando-se no confronto daquele comentário com o conhecimento que Averróis pôde ter da Ética Nicomaqueia propondo-nos assim com competência e autoridade uma "leitura aristotelizante" da mais importante das obras platónicas. Eis um episódio da história da filosofia que surpreenderá decerto os mais interessados dos seus leitores. Sabe-nos bem sublinhar o relevo desta dissertação académica na língua portuguesa, tanto mais que é escassa a produção de mérito e de confiança sobre a produção filosófica arábico-islâmica. Entre nós, além dos trabalho de Catarina Belo, mas sem nos demorarmos sobre o título que também nós publicámos Falsafa. Breve introdução à filosofia arábico-islâmica, Coimbra 2006 - e também sem o fazermos sobre o desconhecimento da A. sobre esta nossa monografia, é escassa para não dizer quase insignificante a produção literária académica sobre Averróis, pelo que nos restará concentrarmo-nos nas principais conclusões de que o leitor mais poderá beneficiar com a leitura da presente dissertação de 
doutoramento, o que faremos numa curta enumeração após uma não menos rápida descrição do conteúdo desta a todos os títulos louvável monografia. Depois de uma parte introdutória, apesar de tudo vasta (pp. 19-75), de apresentação do autor e da sua obra, e antes de um Epílogo que nos oferece a tradução do latim do Livro VI do Comentário Médio sobre a Ética Nicomaqueia (pp. 225-243), versão feita com a colaboração de Anna Lia A. de Almeida Prado, o grosso da dissertação versa, com não podia deixar de ser, sobre "A Arte de Governar" (pp. 79-224), introduzindo, designadamente, a "Ética e Política na Falsafa", para logo se entrar na justificação de um Comentário sobre a República, dirigindo a "leitura aristotelizante" de Platão, e discutindo ainda os dois temas seguintes: a virtude do governante e as qualidades essenciais ao governante. Em quase todos os capítulos a A. presenteia-nos com alguns excursos de maior ou menor erudição, mas sempre generosos e não menos saborosos, quais: mitos, fábulas, mentiras e artifícios (pp. $137 \mathrm{sg}$ ), questões de vocabulário (pp. 155sg), e questões conceituais (pp. 212sg); não será demais enfatizarmos a relevância das discussões vocabulares - notemos que a A. domina o árabe e, tal como nós mesmo preconizamos, teve o bom senso de publicitar previamente os seus critérios de transliteração - e também dos dois últimos apartados. É de louvar ainda o cuidado que a A. prestou à confeção da bibliografia (pp.305-331) e, coisa cada vez mais rara, e no entanto cada vez mais fácil de concretizar, aos índices, neste tipo de obra de feições obrigatoriamente translinguísticas ainda mais urgentes. Pena foi que as notas ficassem arrumadas no final da obra, abandonando-se assim a maior facilidade de leitura segundo o velho critério, tão mais cómodo e rápido, do pé de página. Porquê, enfim, lermos urgentemente esta obra? Porque a sua A. exemplifica bem, e concretiza ainda melhor, o que é ou deve ser um trabalho académico universitário; não menos por causa da mais valia que a publicação de um trabalho assaz meritório sobre um dos mais importantes pensadores ocidentais passa a deter no nosso mundo lusófono das publicações de confiança; ou ainda porque a A. não escondeu o facto da dificuldade do trabalho ibnruxdista - seja pelo entrelaçamento Nicomaqueia/República, seja pelo apoio em Alfarabi, seja por fim pelo criticismo de Averróis relativamente às soluções políticas do seu tempo e do seu espaço - e fez dele uma peça importante da sua construção hermenêutica. Depois, e mais importante ainda, pelas suas conclusões e/ou descobertas, a saber: a prova de que a Nicomaqueia tem uma incidência teórica enquanto a República tem-na prática, no que toca à ciência política, evidentemente; a hermenêutica dos Livros I e II no problemático quadro das virtudes, de maneira tópica: Platão, Aristóteles e Alfarabi; a extensão das virtudes aristotélicas à problemática da cidade ideal; acima de tudo a descoberta da A. sobre algumas passagens onde Averróis critica a dinastia almóada sob a qual decorreu a sua ação de intelectual comprometido. Oxalá esta dissertação possa, entre nós, servir de exemplo e estímulo contra a maré bolonhesa da simplificação doutoral.

Mário Santiago de Carvalho 